Historia Slavorum Occidentis

2017, nr 2 (13)

ISSN 2084-1213

DOI: $10.15804 / \mathrm{hso} 170201$

\author{
Marek Kornat (Warszawa)
}

\title{
Akt 5 listopada a umiędzynarodowienie sprawy polskiej podczas Wielkiej Wojny. Uwagi historyka dyplomacji
}

Słowa kluczowe: Manifest dwóch cesarzy z 5 listopada 1916 r., sprawa polska, pierwsza wojna światowa, Rewolucja Lutowa w Rosji

Keywords: A declaration of two emperors of $5^{\text {th }}$ November 1916, the Polish cause, World War I, the February Revolution in Russia

\begin{abstract}
The author engages in polemics with the thesis that the Act of $5^{\text {th }}$ November was a breakthrough in Poland's efforts to regain its statehood. However, this declaration of establishment of the Polish state made by the governments in Berlin and Vienna and the Western powers (France and Great Britain) were not able to force Russia to acknowledge Poland's independence. There was no such need as the other countries wanted Russia to forge an alliance as part of the Triple Entente.
\end{abstract}

Podczas Wielkiej Wojny miesiąc listopad przestał być dla Polaków „niebezpieczną porą", jak stwierdził Mikołaj I po zdławieniu Powstania Listopadowego. Przyniósł proklamację państwowości polskiej. Nastąpiło to w 101 lat po historycznych uchwałach Kongresu Wiedeńskiego i 119 lat po prusko-rosyjskiej konwencji z 1797 r. zapowiadającej zatarcie imienia Polski na zawsze i obwieszczającej jej „rozbiór całkowity, ostateczny i nieodwołalny” (demembrement général, definitive et irrevocable) ${ }^{1}$.

1 Cyt. za K. Lutostański (ed.), Les Partages de la Pologne et le lutte pour indépendence. Recueil des actes diplomatiques, Traités et documents concernant la Pologne, t. 1, Paris 1918, s. 224. 
Na użytek niniejszych rozważań interesować nas będzie tylko parę pytań: co Akt dwóch cesarzy dał narodowi polskiemu? Co przyniósł w zmaganiach o sprawę polską na arenie międzynarodowej? Czy był przełomem, czy tylko złudzeniem przełomu? Jak historyk polski - z dystansu pełnego stulecia - oceniać powinien to wydarzenie?

O sprawie polskiej podczas pierwszej wojny światowej napisano już tak wiele, że bardzo trudno jest o nowe myśli na polu interpretacji faktów, które od dawna już znamy. Jedno wszakże jest konieczne - tj. polemika z tezą o przełomowości Aktu 5 listopada z punktu widzenia walki o niepodległą Polskę. To też jest celem niniejszych refleksji.

\section{I}

Pierwsze dwa lata Wielkiej Wojny nie przyniosły żadnych rozstrzygnięć w sprawie polskiej. Oprócz obietnic ze strony mocarstw wojujących, nie zaistniały żadne posunięcia o charakterze nieodwracalnym. Żadne z nich nie było żywotnie zainteresowane powołaniem do życia państwa polskiego.

„(...) korzystne i bezpieczne rozwiązanie sprawy polskiej nie istnieje dla nas w ogóle" - mówił w Reichstagu kanclerz Rzeszy Niemieckiej Theobald Bethmann Hollweg ${ }^{2}$. Niezaprzeczalnie wypowiedział w tych słowach stwierdzenie głęboko prawdziwe z punktu widzenia niemieckiej mocarstwowej racji stanu, tak jak ją wówczas pojmowano.

Nie wchodziła w rachubę realizacja koncepcji trialistycznej, o której rozprawiali politycy obozu pro-austriackiego, jaki skupił się wokół Naczelnego Komitetu Narodowego z prof. Władysławem Leopoldem Jaworskim na czele. Jej wejście w życie nie było możliwe z powodów wewnętrznego porządku w dualistycznej monarchii. Jeszcze 2 II 1917 r. premier węgierski Stefan Tisza złożył stanowczy protest przeciw ewentualnemu przyłączeniu powołanego już do życia Królestwa Polskiego do monarchii dualistycznej. Kierował się nie antypatią do Polaków, tylko oczywistym przeświadczeniem, iż to rozwiązanie musiałoby dokonać się ze stratą dla węgierskiego stanu posiadania, tak jak ukształtowała go ugoda (Ausgleich) z 1867 r. ${ }^{3}$ Program trialistyczny nie miał też poparcia Berlina a głos Rzeszy Niemieckiej był przecież decydujący.

2 Stwierdzenie kanclerza cyt. za P. Wandycz, Rozbiory Polski i dyplomacja państw zaborczych (refleksje w dwóchsetna rocznicę), [w:] tenże, $Z$ dziejów dyplomacji, Londyn 1988, s. 39.

3 C. Smogorzewski, La Pologne restaurée, Paris 1927, s. 261. 
Nie należy zapominać, iż podczas Wielkiej Wojny toczyła się niemiecko-austriacka rywalizacja o Polskę - jak pisał swego czasu Leon Grosfeld ${ }^{4}$.

Spośród państw ówczesnej Europy naprawdę pełnego poparcia programowi trialistycznemu udzielała jedynie Stolica Apostolska, lecz - z racji oczywistych było ono jedynie moralne. „Nie można pojąć, żeby Polska wolała być maleńkim ściśniętym państwem, zamiast żeby wejść w skład Austrii, gdzie by przecież przy swoich 23 milionach rządziła. Miałaby przez Austrię wpływ na całą Europę" - usłyszał 2 III 1916 r. w Watykanie Roman Dmowski, kiedy przyjmował go sekretarz stanu Benedykta XV, kard. Pietro Gasparri'.

Dla Polski nie wiele mogły zrobić wchodzące w skład Trójporozumienia mocarstwa Zachodu - Francja i Wielka Brytania, nawet gdyby w poruszeniu sprawy polskiej dostrzegły własny interes. Francję powstrzymywał od działania sojusz z Rosją. Dla niego nie było alternatywy. Kiedy już na początku 1916 r. ambasador Maurice Paléologue „dyskretnie” poruszył problem Polski, usłyszał z ust Siergieja Sazonowa, że podjęcie sprawy polskiej przez Francję oznacza rozpad sojuszu z Rosją, zbliżenie rosyjsko-niemieckie, które dla Francuzów przyniesie nowy Sedan, tak jak doświadczył tego Napoleon III siedem lat po swoim zaangażowaniu w poparcie powstania styczniowego ${ }^{6}$. Szczęśliwie dla Polaków już w drugiej połowie 1916 r. ujawnił się dotkliwy kryzys autokratycznej monarchii rosyjskiej, a jego oblicze ukazało się z całą mocą wiosną następnego roku.

W odbudowaniu państwa polskiego nie znajdywała swego interesu Wielka Brytania, upatrując w nim raczej obciążenie i przeszkodę dla zachowania klasycznej równowagi sił. Brytyjska ocena szans jakiegokolwiek rozwiązania problemu polskiego była wybitnie sceptyczna. Znany historyk Rosji prof. Bernard Pares, przygotował dla Foreign Office specjalne memorandum o kwestii polskiej, a da-

4 D. Szymczak, Między Habsburgami a Hohenzollernami. Rywalizacja niemiecko-austrowegierska w okresie I wojny światowej a odbudowa państwa polskiego, Kraków 2009; Starsze opracowanie L. Grosfelda, Polityka mocarstw centralnych wobec sprawy polskiej w latach pierwszej wojny światowej (Warszawa 1962) zachowuje pewną wartość ́́ródłową. Zagadnienia te obecne pozostają również w nowym naświetleniu relacji Berlin-Wiedeń podczas Wielkiej Wojny pióra Alexandra Watsona: Ring of Steel. Germany and Austria-Hungary at War, 1914 -1918 (London 2014).

5 J. Zdanowski, Dziennik, t. I: 22 VI 1915-29 IV 1917, oprac. J. Faryś (et al.), Szczecin 2013, s. 219-211.

6 Zob. Sz. Askenazy, Uwagi, Warszawa 1924, s. 447-448. 
tował je na 15 VI 1915 r. Rozważania swe kończył zaś stwierdzeniem, iż „the Polish question, though it progresses, has yet far to go for any real settlement"7.

Rządy w Paryżu i Londynie oraz Rzymie udzieliły poparcia dla Manifestu rosyjskiego wodza naczelnego armii Wlk. Księcia Mikołaja Mikołajewicza z 14 VIII 1914 r. do narodu polskiego. Przypomnijmy, iż zawierał on obietnicę zjednoczenia ziem polskich po zwycięstwie w ramach państwa rosyjskiego oraz udzielania im autonomii językowej, kulturalnej i religijnej ${ }^{8}$.

W przypadku Francji milczenie w kwestii polskiej było wymuszone. Kamieniem węgielnym pozostawała teza, iż Francja nie może utracić Rosji jako alianta, którego pozyskała w latach 1891-1894. Było tak niezmiennie, chociaż Rosja od września 1914 r. ponosiła na froncie kolejne klęski.

W ocenie brytyjskiej „some kind of home rule for Poland” to maksimum tego co Polska - za przyzwoleniem Europy - może otrzymać. Takie stanowisko wypowiedział jasno lord Arthur Balfour, w znanym memorandum z 4 X 1916 r. ${ }^{9}$ Dokument ów nosił tytuł The Peace Settlement in Europe. Balfour pisał w nim: „Obawiam się, że nowa Polska cierpiałaby na te same choroby, które spowodowały śmierć dawnej Polski, że byłaby areną nieustannych intryg pomiędzy Niemcami a Rosją, i jej istnieniem, nie sprzyjając bynajmniej sprawie europejskiego pokoju stwarzałoby, nieustanne powody do europejskich zamieszek. Co więcej, nawet gdyby - w co wątpię - taka Polska była w stanie odgrywać rolę skutecznego państwa buforowego, wcale nie jestem pewny, czy istnienie państwa buforowego pomiędzy Niemcami a Rosją leżałoby w interesie Europy Zachodniej. Gdyby, zwolnione od wszelkiej obawy nacisku ze strony Rosji, Niemcy mogły zupełnie swobodnie skierować całą swą siłę w kierunku zaspokajania ich ambicji na zachodzie, Francja i Wielka Brytania mogłyby być poszkodowane. Nie jestem również pewny, czy odcięcie Rosji od jej zachodnich sąsiadów nie skierowałoby jej zainteresowań w kierunku Dalekiego Wschodu w stopniu, który by mógł

7 The National Archives [TNA] (London), Foreign Office, 371, vol. 2445, dok. 109226. Do Foreign Office dokument wpłynął dopiero 9 VIII 1915 r.

8 Kształt tej autonomii oraz regulacja prawna statusu ziem polskich wewnątrz imperium rosyjskiego - nie został nigdy sprecyzowany. Poufne deliberacje prowadziła na ten temat specjalna komisja pod przewodnictwem ministra spraw zagranicznych Sazonowa.

9 TNA, Cabinet Papers, vol. 37/157/7. Zob. też uwagi historyków brytyjskich w najpełniejszym jak dotychczas opracowaniu polityki brytyjskiej podczas Wielkiej Wojny: C. J. Lowe, M. L. Dockrill, The Mirage of Power, Vol. 2: British Foreign Policy 1914-1922, London-Boston 1972, vol. 3, s. 567. 
wzbudzić zaniepokojenie brytyjskich mężów stanu. Im bardziej Rosja jest mocarstwem europejskim, a nie azjatyckim, tym lepiej dla wszystkich" ${ }^{\prime 1}$.

W ten sposób w wewnątrz-brytyjskiej dyskusji, toczącej się w Foreign Office na temat celów wojennych, Balfour opowiedział się przeciwko memorandum Ralpha Pageta i Williama Tyrella (również z października 1916 r.), które zakładało odbudowanie Polski jako jeden z celów wojny ${ }^{11}$. Analizując te słowa, Wiktor Sukiennicki dodał komentarz, stwierdzając że to rozumowanie „wcale nie było niedorzeczne z brytyjskiego punktu widzenia" ${ }^{\prime 2}$. Trzeba przyznać mu zasadniczą rację. Rzeczoznawcy z Foreign Office, opracowujący od wiosny 1916 r. nowe problemy międzynarodowe, jakie stanęly na porządku polityki międzynarodowej, rozpatrywali problem Polski jako zagadnienie usytuowane w ramach Imperium Rosyjskiego.

Prawdopodobnie nie istnieje konkretny dokument dający pełne ujęcie rosyjskich celów wojny na początku zmagań militarnych. Z powodu wątpliwości co do swego pochodzenia, trudno bowiem za taki uznać głośne 13 „punktów Sazonowa” z jesieni 1914 r. ${ }^{13}$ Niemniej nie może być sporu, że ambicjom terytorialnym Niemiec odpowiadały niemniej dalekosiężne aspiracje Rosji. Przedmiotem ambicji Rosji było zdobycie możliwie największych korzyści terytorialnych w Europie, jakich uzyskanie nie okazało się osiągalne nigdy w jej dotychczasowej historii. Głównym obiektem było opanowanie Konstantynopola i Cieśnin Czarnomorskich ${ }^{14}$. W Petersburgu dążono do zdobycia Prus Wschodnich i Galicji Wschodniej oraz Śląska Południowego (Górnego) i Poznańskiego. Galicja zachodnia byłaby przyłączona do Królestwa. Zjednoczone w ten sposób ziemie polskie dostałyby jakiś rodzaj autonomii ${ }^{15}$.

10 W. Sukiennicki, Balfour a Polska, Zeszyty Historyczne, z. 17, (1970), s. 41.

11 K. J. Calder, Britain and the Origins of the New Europe 1914-1918, London-New York 1976, s. 99.

12 W. Sukiennicki, Balfour a Polska, s. 41.

13 W. A. Renzi, Who Composed "Sazonov's Thirteen Points? A Re-Examination of Russia's War Aims of 1914, American Historical Review, vol. 88, no 2, (1983), s. 349.

14 Ostatnie ujęcie w historiografii polskiej dał A. Achmatowicz, Polityka Rosji w kwestii polskiej w pierwszym roku Wielkiej Wojny 1914-1915, Warszawa 2003, s. 45-86. Zob. również zbiór studiów historyków amerykańskich: Russian Diplomacy and Eastern Europe 1914-1917, ed. A. Dallin, New York 1963.

15 Zarys tej części planu Sazonowa powstał w kontaktach rosyjskiego ministra spraw zagranicznych z Dmowskim, jak przyjmuje K. Kawalec, Roman Dmowski, Poznań 2016, s. 269. 
O ile latem 1914 r. w rosyjskich koncepcjach pojawiła się tylko nieszczera zresztą myśl o autonomii zjednoczonych ziem polskich wewnątrz imperium, to w czasie późniejszym następowała modyfikacja tej koncepcji. Współarchitekt „punktów Sazonowa”, ks. Eugeniusz Trubecki formułował w styczniu 1916 r. myśl o „niepodległym” państwie polskim, ale związanym z Rosją ${ }^{16}$. Lider liberalnej opozycji rosyjskiej, prof. Paweł Milukow, wypowiedział wiosną 1916 r. pogląd, że w razie klęski mocarstw centralnych Polska musi dostać dostęp terytorialny do morza poprzez tzw. Prusy Zachodnie, a Prusy Wschodnie pozostana niemiecką wyspą - ale o tym zadecyduje pokój na frontach ${ }^{17}$. Ze słów tych wypływa idea „jakiegoš” państwa polskiego, ale związanego z Rosją.

\section{II}

Nie jest intencją autora niniejszego eseju rozważać na nowo genezę Aktu 5 listopada. Jasne pozostaje, iż „inicjatywa mogła wyjść tylko od Niemiec” - jak zauważył Daniel Beauvois ${ }^{18}$.

Nie pretendując do żadnych nowych ustaleń, poprzestaniemy jedynie na stwierdzeniu, iż o posunięciu tym zadecydowały oczywiście Niemcy - a krok był motywowany wymogami wojny, przede wszystkim pozyskaniem świeżego żołnierza w obliczu kurczenia się własnych rezerw, na co wskazywali główni architekci niemieckiej strategii wojennej, feldmarszałek von Paul von Hindenburg i gen. Erich Ludendorf. Ten ostatni, w liście do sekretarza stanu w Auswärtiges Amt Arthura Zimmermanna powiedział właściwie wszystko: „Polak to dobry żołnierz... Trzeba zrobić Wielkie Księstwo Polskie z Warszawą i Lublinem, a następnie armię polską pod dowództwem niemieckim"19. Luddendorf był zwolennikiem poboru na ziemiach opanowanego Królestwa ${ }^{20}$. Na to jednak rząd niemiecki się nie zdecydował, uznając, że dobrowolny zaciąg da większe rezultaty, ale wymaga on politycznej oferty wobec narodu polskiego.

16 Wywiad dla gazety „Russkoje Słowo” - cyt. za T. Piszczkowski, Anglia a Polska 1914 -1939 w świetle dokumentów brytyjskich, Londyn 1975, s. 3.

17 Wywiad prof. Milukowa dla szwedzkiego pisma „Berlingske Tidende” (przypomniany w piśmie endeckim - „Myśl Narodowa”, nr 25, (1923), s. 4).

18 D. Beauvois, La Pologne. Histoire, société, culture, Paris 2004, s. 301.

19 Cyt. za T. Piszczkowski, Odbudowanie Polski 1914-1921. Historia i polityka, Londyn 1969, s. 44.

20 A. Nowaczyński, Dokumenty historyczne z Wojny Europejskiej, z. I: Od roku 1914-1915, Warszawa 1922, s. 164. 
Motyw pozyskania żołnierza nie wyczerpuje genezy listopadowej decyzji. U jej podstaw tkwiła niemiecka wizja nowych państw narodowych w Europie Środkowej. 12 VIII 1916 r. nastąpiło definitywne porozumienie rządów Rzeszy Niemieckiej i Cesarstwa Austro-Węgier w Wiedniu w sprawie proklamacji państwa polskiego. Zawarli je szefowie rządów - Bethmann Hollweg i István Burian.

Akt dwóch cesarzy nie przesądzał granic proklamowanego państewka. Jego twórcy „rozporządzali własnością cudzą” - jak to ujął Szymon Askenazy ${ }^{21}$. Utrzymano system okupacji na jego terytorium do zakończenia działań wojennych. Polakom oddano do rąk własnych jedynie dwie dziedziny życia państwowego - sądownictwo i szkolnictwo.

Wyodrębnić można zasadniczo trzy koncepcje kanclerza Bethmana Hollwega w sprawie Polski: (1) zgodzić się na oddanie Królestwa Austrii; (2) oddać Królestwo Rosji, ale anektować „pas graniczny”; (3) stworzyć państwo polskie związane z Niemcami. Koncepcja pierwsza upadła. Druga mogła wejść w życie tylko w wypadku kompromisowego pokoju z Rosją, na co kanclerz niemiecki liczył, uznając, że upadek Sazonowa latem 1916 r. zwiększa takie możliwości. Kalkulacje te jednak się nie spełniły. Pozostała opcja trzecia - i ona znalazła realizację na drodze Aktu 5 listopada.

Mówiąc o odbudowaniu Polski, Niemcy kategorycznie wykluczali jakiekolwiek możliwości cesji terytorialnej z własnego stanu posiadania na rzecz tego państwa. W listopadzie 1916 r., a więc zaraz po proklamacji odbudowy Królestwa Polskiego, pruski minister spraw wewnętrznych Friedrich Loebell mówił w pruskiej Izbie Poselskiej, iż „nad tym nie warto tracić słowa, że dla państwa pruskiego jest każda piędź ziemi na wschodniej granicy (...) świętą i niepozbywalną"22. Na pewno wykluczona była wszelka myśl o jakiejkolwiek cesji terytorialnej na rzecz państwa polskiego ze strony Prus. Przeciwnie, militaryzm niemiecki wygenerował nowe żądania terytorialne wobec Królestwa Polskiego, które Akt 5 listopada przytłumił, lecz nie zniweczył. Jednym zaś z bardziej znanych projektów z początku Wielkiej Wojny miał być powrót do znanej od stulecia tzw. linii Knesebecka, o której sobie w Berlinie przypomniano ${ }^{23}$. Dużo bardziej ograniczone koncepcje

21 Sz. Askenazy, Uwagi, s. 91.

22 Cyt. za wydawnictwem Sprawa polska w izbie poselskiej sejmu pruskiego w Berlinie wedtug zapisów stenograficznych, Poznań 1917, s. 10.

23 Pruski generał Karl Friedrich von dem Knesebeck przedłożył w 1813 r. cesarzowi Aleksandrowi I projekt podziału Księstwa Warszawskiego według linii wyznaczonej rzekami: Wisły (od ujścia Pilicy do okolic Warszawy), następnie wzdłuż Narwi i Niemna. O projekcie tym 
„pasa granicznego” popierał gen. Max Hoffmann - szef Wielkiego Sztabu Generalnego, co wszakże natrafiło na sprzeciw ministra spraw zagranicznych Richarda von Kühlmanna ${ }^{24}$.

Tekst Aktu dwóch cesarzy głosił, że nowa Polska będzie „selbständig” a nie „unabhängig”. Ponadto byłoby ono złączone z mocarstwami centralnymi, a związek ten określono dobrze później znanym słowem „Anschluss”25. Powstawała Polska „dopiero zamierzona, a już okrojona, samoistna a podległa”. I zanim istnieć zaczęła „już zachwiała się w najistotniejszych fundamentach swojego mniemanego istnienia" 26 .

Państewko polskie po zakończeniu wojny miało zostać wkomponowane w ustrój niemieckiej Mitteleuropy - rozciągającej się „od Polski po Finlandię”27. Taki system nie byłby - jak wszystko na to wskazuje - wytworem wolnościowych dążeń ujarzmionych narodów, jak tego pragnęli twórcy tej wizji, liberałowie niemieccy Friedrich Naumann i Gottfried Traub ${ }^{28}$. Gustav Stresemann - późniejszy kanclerz i minister spraw zagranicznych Rzeszy głosił wizję liczącego 150 milionów ludzi bloku gospodarczego pod hegemonią niemiecką, aby stawić czoła rosnącej potędze gospodarczej Stanów Zjednoczonych ${ }^{29}$. Po wojennym zwycięstwie Rzeszy nowy ład zostałby oparty raczej o militaryzm. Patronowałby mu z pewnością „duch pruski”. Jego podstawy oparte zostałyby o wspólnotę gospodarczą wielkiej przestrzeni (Grossraumwirtschaft).

przypomniano sobie w niemieckim Wielkim Sztabie Generalnym w czasie pierwszej wojny światowej, dodając nowe uzasadnienie strategiczno-wojskowe i gospodarcze. (Szerzej o tych sprawach traktuje J. Pajewski, Polityka mocarstw centralnych wobec Polski podczas pierwszej wojny światowej, Roczniki Historyczne, R. 28, (1962), s. 22).

24 O tym problemie - zob. J. W. Wheeler-Bennett, The Forgotten Peace. Brest-Litovsk. March 1918, New York 1938, s. 199-200.

25 Sz. Askenazy, Uwagi, s. 97-98.

26 M. Sokolnicki, Polska w pamiętnikach Wielkiej Wojny 1914-1918, Warszawa 1925, s. 9.

27 A. Chwalba, Samobójstwo Europy. Wielka Wojna 1914-1918, Kraków 2014, s. 593-608.

28 F. Naumann, Mitteleuropa (niemiecki tekst ukazał się jesienią 1915 r.). Naumann wyraźnie twierdził, że państwo polskie winno być komponentem „Mitteleuropy”, a co więcej, dowodził, iż tylko w ramach tego systemu państwo polskie mogłoby powstać (cytujemy wydanie angielskie: Central Europe, London 1916, s. 107-108). Zob. także szkic Naumanna, Was wird aud Polen? (Berlin 1917).

29 Zob. A. Tooze, U progu Wielkiego Kryzysu. Wielka Wojna i przebudowa światowego porządku 1916-1931, Oświęcim 2016, s. 116. 


\section{III}

Jak pisał Immanuel Geiss, wydając Akt 5 listopada rządy mocarstw centralnych przecięły szanse na kompromis ze „starą Rosją” - chylącą się do upadku, czego jednak wówczas z całą jasnością nie widziano. Dodajmy, iż kanclerz Bismarck wyznawał tezę, iż taktyczne powołanie do życia państewka polskiego w okolicznościach przyszłej wojny przeciw Rosji nie przekreśli takich możliwości, a raczej umożliwi pokonanie państwa i narzucenie mu pokoju na własnych, niemieckich warunkach. Wypadki z przełomu 1916/1917 r. nie potwierdziły tej kalkulacji. Jest jednak konieczne powiedzieć, że akcja na rzecz utworzenia państewka polskiego niekoniecznie jest „sprzeczna z całą tradycją pruską” - jak sądził Michał Sokolnicki ${ }^{30}$.

Odpowiedź na Akt 5 listopada należała przede wszystkim do Rosji jako mocarstwa dysponującego prawnie olbrzymią częścią terytoriów polskich, chociaż zostały one utracone w wyniku przegranych na froncie. Jej stanowisko nie oznaczało jednak zwrotu w podejściu do sprawy polskiej.

Jak wiadomo, Mikołaj II w swym rozkazie do armii lądowej i floty z 25 XII 1916 r. powtórzył de facto treść orędzia wlk. ks. Mikołaja Mikołajewicza z 14 VIII 1914 r. Deklaracja ta pozostaje „ostatnim słowem” caratu w sprawie polskiej. Carat nie dał Polakom żadnej oferty ponad to, co obiecał Manifest Wodza Naczelnego z 1914 r. Późniejsze oświadczenia nie rozszerzyły jej nawet na jotę.

Proklamacja dwóch cesarzy nie wywołała rewolucyjnego przełomu w sprawie rozwiązania sprawy polskiej.

Relacjonując francuskiemu ministrowi spraw zagranicznych Aristie'owi Briandowi swoje rozmowy w Piotrogrodzie - między innymi na temat kwestii polskiej - ambasador Maurice Paléologue pisał 8 XI 1916 r. niezwykle jasno: „Wedle mojej świadomości rząd francuski nigdy nie patronował u rządu rosyjskiego niczemu innemu, jak tylko autonomii Polski całej" (l'autonomie de la Pologne intégrale) ${ }^{31}$. W gruncie rzeczy odpowiadało to idei przyłączenia do Rosji - w razie zwycięstwa nad Niemcami - ziem polskich zaboru pruskiego i zachodniej części Galicji do Królestwa Kongresowego, zaś Galicji Wschodniej do Rosji - jak głosiło wspomniane już 13 „punktów Sazonowa” z września 1914 r.

\footnotetext{
30 M. Sokolnicki, Polska w pamiętnikach, s. 9.

31 Cyt. przez Askenazego, Uwagi, s. 455 (podane w języku francuskim, tłumaczenie moje - M. K.).
} 
W imieniu mocarstw Zachodu (Francji, Wielkiej Brytanii i Włoch) 10 I 1917 r. minister spraw zagranicznych Briand zapewnił rząd rosyjski o pełnej afirmacji treści carskiego orędzia do armii lądowej i floty z 25 XII 1916 r. w kwestii polskiej. W przededniu wybuchu Rewolucji Lutowej w Rosji toczyły się tajne rokowania międzyalianckie. Miały charakter konsultacji w przedmiocie ustalenia celów wojny dla mocarstw ententy ${ }^{32}$.

W marcu 1917 r., między mocarstwami ententy zawarte zostało poufne porozumienie, na mocy którego Francja i Wielka Brytania przyznały Rosji prawo do swobodnego oznaczenia swych granic zachodnich w zamian za analogiczne poparcie Rosji dla takich samych praw Francji w stosunku do pokonanych Niemiec. Rozwiązanie takie akceptował premier francuski Alexandre Ribot i minister Briand. Zasady racji stanu i geopolityki święciły raz jeszcze triumf. „Sprawa polska" miała pozostać wewnętrzną sprawą Rosji.

Rezolucja rządu francuskiego z 10 III 1917 r. dawała gwarancję zostawienia Rosji wolnej ręki w uregulowaniu kwestii polskiej - w zamian za prawo Francji do swobodnego oznaczenia swej granicy wschodniej z Niemcami na Renie. Dzień później ambasador rosyjski w Paryżu Aleksander Izwolski pisał do Piotrogrodu: „Le gouvernement de la République française, soucieux de confirmer toute l'importance et la signification des accords conclus avec le gouvernement russe, en 1916, à l'effet de régler, à la fin de la guerre actuelle, la question de Constantinople et des Détroits d'une façon conforme aux aspiration de la Russie; soucieux, d'autre part, d'assurer à son alliee, tant au point de vue militaire qu'au point de vue industriel, toutes les garanties désirables pour la sécurité et le développement économique de l'Empire, reconnaît à la Russie la complète liberté de déterminer à son gré ses frontières occidentales" ${ }^{33}$. Rewolucja Lutowa, następnie bolszewicka i opuszczenie ententy przez Rosję, ustalenia te przekreśliły - ostatecznie i nieodwracalnie.

W przededniu Rewolucji Lutowej brytyjskie, francuskie i rosyjskie koncepcje rozwiązania sprawy polskiej znajdowały w gruncie rzeczy wspólną płaszczyznę. Płaszczyzną tą pozostawały dwie idee: bliżej nie zdefiniowanej autonomii dla Polski i zjednoczenia ziem polskich w ramach Imperium Rosyjskiego, pod suwerennością tego państwa.

32 Szczegółowe i wnikliwe ujęcie tych działań dyplomacji mocarstw sprzymierzonych z punktu widzenia polityki francuskiej dał A. Pingaud, Histoire diplomatique de la France pendant la Grande Guerre, vol. 2, Paris 1937.

33 S. Filasiewicz (ed.), La Question polonaise pendant la Guerre mondiale, Paris 1920, s. 140-141 . 
Deklaracja Brianda, złożona w imieniu mocarstw sprzymierzonych 11 III 1917 r., pomijała sprawę polską wśród celów wojny mocarstw sprzymierzonych, zostawiając Rosji decyzję w jej przedmiocie. Trzy mocarstwa ententy przyznały jej prawo do uregulowania zachodniej granicy Imperium i kwestii polskiej według jej własnych potrzeb. Konfirmowały wolę udzielenia narodowi polskiemu autonomii. „Sprawa polska” miała nadal pozostać wewnętrzną sprawą Rosji.

Najmocniej wyraził tę myśl premier Italii Paolo Boselli, który zapewnił cara Mikołaja II, iż jego intencje, wypowiedziane w rozkazie do armii lądowej i floty z 25 XII 1916 r., uważa za jasne. Zapowiadają one „autonomię wszystkich zjednoczonych ludów polskich" 34 .

Oczywiście nie wiemy, jaki obrót wzięłyby wypadki po zakończeniu wojny i w jakiej mierze zrealizowane zostałyby podczas kongresu pokojowego uzgodnienia mocarstw ententy z 5 IX 1914 r., zapewnienia udzielone Rosji 10 I 1917 r. oraz postanowienia deklaracji Brianda z 11 marca tego roku. Wolno tylko wyrazić przypuszczenie, iż rządom w Paryżu i Londynie nieobce byłoby pragnienie dania Rosji zadośćuczynienia za udział w wojnie po stronie koalicji i za wymuszenie na niej większego zaangażowania na froncie wschodnim, czemu służyła przede wszystkim międzysojusznicza konferencja w Piotrogrodzie w styczniu i lutym 1917 r. ${ }^{35}$ Ale jedno wydaje się niezaprzeczalne. Wpływ Rosji na oblicze ładu pokojowego po Wielkiej Wojnie byłby funkcją jej siły jako państwa w chwili zakończenia działań militarnych.

Dużo więcej niż mężowie stanu w Paryżu, Londynie czy Rzymie mógł powiedzieć Woodrow Wilson, bo reprezentował mocarstwo nie związane zobowiązaniami na rzecz kogokolwiek. Niewątpliwie uznał on, że powoływane do życia państewko polskie w dawnym Królestwie Kongresowym będzie solucją problemu polskiego.

Jak ujawnił ambasador Stanów Zjednoczonych w Niemczech James Watson Gerard, w książce My Four Years in Germany już w r. 1917, uspokajał on kanclerza Bethmann Hollwega, iż Wilson mówił 22 I 1917 r. o Polsce ustanowionej przez Niemcy i Austrię. Było to odpowiedzią na zwierzenia Bethmann Hollwega z jego obaw, że nowe państwo polskie chce zająć terytoria pod panowaniem pruskim i granica polsko-niemiecka będzie przebiegać w miejscu oddalonym

\footnotetext{
34 S. Sierpowski, Stosunki polsko-wtoskie 1918-1940, Warszawa 1975, s. 25.

35 Omówienie tych rokowań dał J. Pajewski, Wokół sprawy polskiej. Paryż-LozannaLondyn 1914-1918, Poznań 1970, s. 54-58.
} 
„na dwie godziny motorem od Berlina”. Co więcej, zechce też upomnieć się o Gdańsk ${ }^{36}$. Zbieżny z wystąpieniem Watsona Gerarda pozostaje list prezydenta do lorda Balfoura ze stycznia lub lutego 1917 r., gdyż dowodzi on pragnienia amerykańskiego męża stanu, aby Polska została odbudowana jak tylko to możliwe „on the lines before the partitions”, co nie łatwo zrozumieć inaczej jak tylko przy założeniu, że chodzi tu o nie naruszanie terytorialnego stanu posiadania Niemiec i Austro-Węgier. Podobnie niejasno brzmią założenia Wilsona, iż to nowe państwo ma być „autonomiczne”, obdarzone "gwarancją ligi pokoju” (czyli czegoś, co później stanie się Ligą Narodów), „albo Rosji” ${ }^{37}$.

Deklaracja dwóch cesarzy - w moim przekonaniu - wpłynęła na kształtowanie się Wilsonowskiej wizji nowej Europy. Należy pamiętać, iż w latach 1914-1916 amerykański mąż stanu wyznawał tezę o konieczności zawarcia przez strony wojujące pokoju bez aneksji, czyli powrotu do terytorialnego status quo, co dla Polaków byłoby najgorsze ${ }^{38}$.

Dobrze znana mowa Wilsona do Kongresu z 22 I 1917 r. przyniosła jednak zerwanie z tą koncepcją. Zawierała passus o niemożliwości trwałego pokoju bez uznania i akceptacji zasady, że „rządzący czerpią wszelką prawowitą władzę z przyzwolenia rządzonych” bowiem „nie istnieje żadne prawo rozporządzania narodami (to hand peoples) i przekazywania ich „spod jednej zwierzchności pod inną zwierzchność, jakby były (czyjąś) własnością". I tu prezydent podał przykład narodu polskiego, co do którego „wszyscy mężowie stanu są zgodni” w tym, że „winna powstać zjednoczona, niepodległa, autonomiczna Polska” ${ }^{39}$. Wzajemna sprzeczność ostatnich dwóch pojęć jest widoczna, ale nie to naonczas było najważniejsze.

Nie ma rozstrzygającego dowodu, że działania dyplomatyczne Ignacego Paderewskiego i jego memorandum wręczone pułkownikowi Edwardowi Mandellowi pod koniec 1916 r. miały bezpośredni wpływ na proklamację Wilsona

\footnotetext{
36 J. Watson Gerard, My Four Years in Germany, New York 1917, s. 369-370. Rozmowa miała miejsce tuż przed odwołaniem amerykańskiego dyplomaty z Berlina, co nastąpiło na dwa miesiące przed wypowiedzeniem wojny temu krajowi przez USA 6 IV 1917 r.

37 M. Biskupski, The United States and the Rebirth of Poland 1914-1918, Dordrecht 2012, s. 247.

38 Zob. A. S. Link, Wilson. The Struggle for Neutrality 1914-1915, Princeton 1960. Kwestia polska nie figuruje w tej rozprawie jako jakiekolwiek zagadnienie.

39 S. Filasiewicz (ed.), La Question polonaise, s. 133-134.
} 
z 22 I 1917 r. ${ }^{40}$ Co do jednego można więc mieć niemal pewność. Otóż bez Aktu 5 listopada nie byłoby zainteresowania Wilsona sprawą polską już w 1917 r. Wydaje się to bezsporne. Ze świadomością, że mocarstwa centralne proklamowały państwo polskie zaś mocarstwa koalicji wyjawiły swoje intencje, deklarując autonomię ziem polskich wewnątrz imperium rosyjskiego - amerykański prezydent mógł wypowiedzieć przypomniane powyżej słowa.

Nie ktoś inny tylko Dmowski wyznał, że proklamacja cesarzy dała sprawie polskiej znaczne usługi. Jego „dyplomacja bez listów uwierzytelniających” stała się od tej chwili niepomiernie skuteczniejsza ${ }^{41}$. Uzasadnienie tej myśli dał w swoim traktacie historyczno-politycznym Polityka polska i odbudowanie państwa.

Po Akcie 5 Listopada sprawa polska jako problem międzynarodowy nie istnieje już tylko na płaszczyźnie humanitaryzmu i uczuć życzliwości do Polaków, które na Zachodzie w niektórych sferach nigdy nie wygasły ${ }^{42}$. Kwestia polska stała się problemem realnej polityki „tu i teraz”, albowiem sprzymierzone mocarstwa musiały się liczyć z obawami, że interes koalicji może ucierpieć, kiedy Niemcy zdołają pozyskać naród polski dla siebie i otrzymać do dyspozycji polskiego żołnierza. Wzmogły się więc naciski, poufne sugestie i rozmaite dyplomatyczne posunięcia wobec rządu w Piotrogrodzie. Ich intensyfikacja nastąpiła między listopadem 1916 a marcem 1917 r. Pamiętajmy jednak, że była bezskuteczna. Są one nie od dzisiaj znane historiografii polskiej, toteż nie ma powodu ich przypominać.

Dużą zasługą Janusza Pajewskiego pozostaje ukazanie nam na nowo i źródłowo międzynarodowych konsekwencji Aktu 5 listopada ${ }^{43}$. Tadeusz Piszczkowski - dyplomata, historyk i publicysta - na kartach swej ogłoszonej w 1969 r. cennej

40 Tak widzi to autor ostatniej monografii na temat zaangażowania Stanów Zjednoczonych na rzecz sprawy polskiej podczas Wielkiej Wojny, M. Biskupski, The United States and the Rebirth of Poland, s. 243.

41 Pojęcie to wprowadził Hans-Henning Hahn, Dyplomacja bez listów uwierzytelniających. Polityka zagraniczna Adama Jerzego Czartoryskiego 1830-1840, tłum. M. Borkowicz, Warszawa 1987.

42 Przykładami niech będą trzy ankiety: Wilhelma Feldmana (Sprawa polska w opinii Europy. Ankieta międzynarodowa zebrana staraniem Redakcji „Krytyki”, Kraków 1900); Henryka Sienkiewicza (zob. D. Pygawko, „Prusy i Polska”: ankieta Henryka Sienkiewicza (1907-1909), Poznań 1994), Kazimierza Woźnickiego (Francja i Polska. Ankieta w sprawie stosunków francusko-polskich urzadzona staraniem Biura Informacyjno-Prasowego Rady Narodowej w Paryżu (Lwów 1912) oraz wypowiedzi przedstawicieli francuskich sfer intelektualnych i politycznych - zob. J. Pajewski, Wokót sprawy polskiej, s. $11 \mathrm{n}$.

43 J. Pajewski, Odbudowa państwa polskiego 1914-1918, Warszawa 2005, s. 127-132. 
książki Odbudowanie Polski 1914-1921. Historia i polityka - wyraził sugestię, iż Akt listopadowy był uzgodniony po cichu z Borysem Stürmerem - premierem Rosji i liderem proniemieckiej grupy u szczytów władzy w Piotrogrodzie. Niemcom chodziło o to, aby w ten sposób wywrzeć na Mikołaju II skuteczny nacisk w kierunku skłonienia go, by zdecydował się na pokój separatystyczny pod groźbą odbudowy Polski i znacznych strat terytorialnych ${ }^{44}$. Poszukiwania w archiwach rosyjskich mogłyby dać - być może - nowe oświetlenie tego zagadnienia.

Amerykański polityk (późniejszy prezydent i znany filantrop) Herbert Hoover wielokrotnie mówił, że 5 XI 1916 r. to pierwszy dzień niepodległości Polski. Wbrew tym pełnym życzliwości dla Polski słowom, listopadowy Akt jeszcze niczego nie przesądzał lub nie wiele rozstrzygał.

Oczywiście trudno nie zauważyć, że proklamacja dwóch cesarzy przyniosła budowę podwalin państewka polskiego, a jeśli coś takiego jak państwo się tworzy - to zawsze w stosunkach międzynarodowych nie łatwo jest odwrócić bieg wypadków i cofnąć się do status quo ante, czyli usunąć je z mapy.

Na pewno Akt 5 listopada stanowił „wydatny krok ku odbudowaniu Polski” ${ }^{45}$. Nie można jednak powiedzieć, że definitywnie umiędzynarodowił sprawę polską i przesądził sam w sobie o egzystencji państwa polskiego.

Był przede wszystkim produktem szczególnych okoliczności wytworzonych w skutek wyczerpywania się niemieckich zasobów ludzkich, niezbędnych w dalszym prowadzeniu wojny. Doszedł do skutku także jako rezultat upadku prób osobnego pokoju z Rosją na bazie terytorialnego status quo. Manifest stanowił wielki manewr polityczny Berlina wpisujący się historię niemieckiej myśli politycznej, której założenia biorą początek od Bismarcka i gen. Alfred Waldersee, a ich istotą była idea powołania do życia państewka polskiego, gdy będzie to konieczne w dalszej wojnie z Rosją. Proklamacja dwucesarska z listopada 1916 r. była nową odsłoną tych planów. Jej novum polegało głównie na tym, że inicjatywę tworzenia państwa polskiego przejmowali Niemcy, nie zostawiając tego zadania Austrii, jak zakładał „żelazny kanclerz”.

Nie akt listopadowy, ale dopiero Rewolucja Lutowa stworzyła realne możliwości poparcia sprawy polskiej przez mocarstwa Zachodu. One nie kierowały się

\footnotetext{
44 T. Piszczkowski, Obudowanie Polski, s. 47-48.

45 Sz. Askenazy, Uwagi, s. 109.
} 
w swojej polityce pragnieniem naprawy świata poprzez zastosowanie zasad sprawiedliwości międzynarodowej, ale chciały za wszelką cenę utrzymać Rosję jako alianta w koalicji antyniemieckiej. Gdyby nie proklamacja Rządu Tymczasowego nowej rewolucyjnej Rosji, nie byłoby szans publicznego podniesienia kwestii polskiej przez rządy w Paryżu i Londynie.

Jakie byłoby położenie sprawy polskiej, gdyby nie upadł carat i Rosja dochowała swym aliantom braterstwa broni - żaden historyk rozstrzygać nie może. Wolno powiedzieć tylko jedno. Wszystko rozstrzygałoby się podczas konferencji pokojowej. Od tego, jaka byłaby wówczas realna siła Rosji, zależałoby bardzo wiele z punktu widzenia urządzenia powojennej Europy Wschodniej. To wszystko jednak możemy oglądać jedynie oczyma wyobraźni historyka.

Mimo Aktu 5 listopada 1916 r. wciąż mogły zaistnieć rozmaite, bardzo niekorzystne dla Polaków scenariusze dalszego rozwoju wydarzeń. Trzy z nich wypada wspomnieć jako wcale nie teoretyczne, chociaż udaremnione przez wybitnie sprzyjającą Polakom historię $e^{46}$.

(1) Możliwość zakończenia wojny na drodze negocjowanego i kompromisowego pokoju, już nie w myśl zachowania terytorialnego stanu posiadania mocarstw sprzed wybuchu Wielkiej Wojny, lecz z zastosowaniem znaczących modyfikacji. Z grudnia 1916 r. pochodzą - przypomnijmy - propozycje mocarstw centralnych w myśl koncepcji ministra spraw zagranicznych Austro-Węgier Buriana ${ }^{47}$. Plan obejmował 17 punktów - w tym m.in. ewakuację Francji i przywrócenie neutralności Belgii w zamian za nietykalność terytorialną czterech państw koalicji (Niemiec, Austro-Węgier, Bułgarii i Turcji). Pojawił się postulat zwrotu Niemcom zajętych przez aliantów kolonii. W punkcie siódmym była mowa o uznaniu niezawisłego Królestwa Polskiego - proklamowanego 5 XI 1916 r. ${ }^{48}$ Projekt upadł w styczniu 1917 r., podobnie jak pięć miesięcy później następna inicjatywa kolejnego ministra spraw zagranicznych imperium habsburskiego

46 Aleksander Bocheński nazwał to zjawisko „koniunkturami geopolityczni” (zob. tenże, Dzieje gtupoty w Polsce. Pamflety dziejopisarskie, Warszawa 1988, s. 9-25).

47 Idea rozmów pokojowych była niemiecka - ale plan austriacki. Zakomunikowano go sprzymierzonym przez państwa neutralne.

48 J. Pajewski, Pierwsza wojna światowa 1914-1918, s. 414. 
Otokara Czernina ${ }^{49}$. Wszystko wskazuje na to, że wojna pod koniec 1916 r. i w pierwszych miesiącach 1917 r. była już nie do zażegnania, aby Europa mogła powrócić do status quo ante bellum, co stwierdził kanclerz Bethmann Hollweg już 5 IV 1916 r., w swej mowie w Reichstagu ${ }^{50}$.

(2) Ewentualne dotrwanie Rosji w obozie mocarstw sprzymierzonych do końca wojny dawało jej udział w kształtowaniu pokojowego ładu i wolną rękę w sprawie określenia losu Polski. Deliberacje rosyjskich sfer rządowych wokół rozwiązania sprawy polskiej, prowadzone w Piotrogrodzie przed wybuchem rewolucji lutowej wskazują, iż nie było woli dania Polakom więcej niż autonomia wewnątrz imperium rosyjskiego. Gdyby przyjąć, iż z Wielkiej Wojny wychodzi Rosja jako liberalna republika - jaką budować chciał Rząd Tymczasowy - nie ma powodu sądzić, że rosyjska oferta dla Polaków byłaby inna niż to, co ofiarował ów rząd w swojej deklaracji z 29 III 1917 r. A była to jedynie formalna niepodległość, wschodnia granica taka, jaką miało Królestwo Kongresowe (ale bez Chełmszczyzny), oraz „wolny sojusz” z Rosją. Tych warunków nowe państwo rosyjskie nie zdołało narzucić Polakom. Imperium rosyjskie załamało się od wewnątrz, a na jego gruzach powstał chaos, który wyzyska odradzająca się Polska. Załamanie się Rosji było dużo ważniejsze niż wszystkie obietnice mocarstw centralnych - i nie chodzi tu o to, że Manifest Rządu Tymczasowego dawał Polakom więcej niż Akt 5 listopada, bo mówił o Polsce nie tylko niepodległej, ale i zjednoczonej ${ }^{51}$. Ono umożliwiło „licytację wzwyż” sprawy polskiej. Czynił to na swój sposób Józef Piłsudski, a na innym polu Roman Dmowski ${ }^{2}$.

(3) Klęska Niemiec na zachodzie, ale zarazem ocalenie zdobyczy na wschodzie przynosiło realizację niemieckiej Mitteleuropy - której podwaliny tworzył traktat

49 Propozycje Czernina zostały odrzucone w maju 1917 r. Jako pośrednik działał ks. Sykstus parmeński. Orędownikiem pokoju był cesarz Karol. Do tych spaw zob. Les pourparlers de paix de 1917 avec l'Autriche-Hongrie. Actes du Colloque universitaire international de Neuchatel, ed. L.-E. Roulet, "Guerre mondiales et Conflits contemporains", no 170, avril 1993. Zob. także J. Pajewski, Pierwsza wojna światowa 1914-1918, s. 438.

50 A. Tooze, U progu Wielkiego Kryzysu, s. 13.

51 G. Wolfs, Czy należało utworzyć Królestwo Polskie w listopadzie 1916 roku?, Zeszyty Historyczne, z. 129, (1999), s. 158.

52 O ile mówi się, iż Piłsudski prowadził politykę „licytacji wzwyż” - mało zwraca się uwagę na to, że własną taktykę podobnej „licytacji” prowadził Dmowski - i tak ją określa K. Kawalec, Roman Dmowski, s. 285-290. 
brzeski z 3 III 1918 r. ${ }^{53} \mathrm{~W}$ jej ramach pozostałaby jedynie egzystencja państewka polskiego - którego zależność od Niemiec byłaby zupełna. Bez dostępu do morza, bez przemysłowych terytoriów Górnego Śląska, bez rolnictwa Wielkopolski - istniałaby Polska bezwolna i będąca gospodarczym zapleczem Rzeszy Niemieckiej. Miałaby tylko jedną zaletę w oczach sfer cudzoziemskich - nie byłaby przeszkodą dla „możnych tego świata” w ich urządzaniu międzynarodowego porządku. Niemcom zabrakło wszakże sił, aby ustanowić system Mitteleuropy i mieścić w nim niepodległą Polskę. Zmuszone przyjąć Traktat Wersalski, uznały w nim zbrodniczy zamach na swój byt narodowy - „pokój kartagiński”, jak głosiła ich propaganda. Ale to już osobna historia.

Nadesłany: 15 II 2017

Nadesłany po poprawkach recenzyjnych: 10 VI 2017

Zaakceptowany: 20 VI 2017

prof. dr hab. Marek Kornat,

Instytut Historii im. Tadeusza Manteuffla

Polska Akademia Nauk

ul. Mielżyńskiego 27/29, 61-725 Poznań

\section{The Act of $5^{\text {th }}$ November and the international nature of the Polish cause during World War I. Comments provided by a diplomacy historian}

The author analyses the international importance of the Act of $5^{\text {th }}$ November from the point of view of the future of Poland in the post-WWI international deal. The declaration of two emperors represented an "important step towards Poland's reconstruction" (as Szymon Askenazy, a Polish historian, observed). However, the declaration failed to ultimately internationalize the Polish cause and determined itself the existence of the Polish state. The document was a product of special circumstances resulting from the fact that Germany was running out of human resources indispensable to continue the war. It was also possible because of the abortive attempts at securing peace with Russia

53 „Zapomnianym pokojem” - nazwał to porozumienie John Wheeler-Bennett (zob. jego The Forgotten Peace. Brest-Litovsk. March 1918, New York 1938). Nie tylko jest on często zapomniany, ale ustanawiał określoną wizję ładu w Europie Środkowo-Wschodniej. Stała się ona wprawdzie epizodem historii, ale nie oznacza to, że nie zaistniała. 
on the basis of a territorial status quo. The declaration represented Berlin's grand-scale political move, connecting with the history of the German political thought with assumptions originated by Bismarck and general Waldersee and revolving around the idea of establishing a small Polish state when it is necessary in the course of a war with Russia. Despite the proclaimed establishment of the Polish state by the governments in Berlin and Vienna, the Western powers (France and Great Britain) were not able to force Russia to acknowledge Poland's independence. They assigned the government in Petrograd the right to deal with the Polish cause at its discretion i.e. to delineate the Western border of the empire according to its will once the acts of war were over. The historian therefore concludes that it was not before the February Revolution in Russia when actual possibilities opened up for the Western powers to support the Polish cause. In their policies, they did not include willingness to make the world a better place by principles of international justice but rather, they intended to maintain Russia as an allied force in the anti-German coalition at all cost. 